\title{
Sosialisasi Covid-19 Dan Pemanfaatan Tanaman Herbal Sebagai Upaya Pemeliharaan Kesehatan Tubuh Di Masa Pandemi Covid-19 Di Desa Tehoru Kabupaten Maluku Tengah
}

\author{
La Rakhmat Wabula*1, Syahfitrah Umamity ${ }^{2}$ \\ 1,2Program Studi Ilmu Keperawatan, STIKes Maluku Husada, Indonesia \\ *e-mail: la.rakhmat.wabula.stikesmh@gmail.com ${ }^{1}$, syahfitrah.umamity@gmail.com²
}

\begin{abstract}
Abstrak
Penyebaran Covid-19 sangat cepat sehingga semua negara di dunia ini sedang menghadapi masalah kesehatan yang sama. Tak terkecuali di Indonesia, hingga saat ini di Kabupaten Maluku Tengah pasien terkonfirmasi positif Covid-19 sudah mencapai 20-an. Hal itu tentu saja membuat semua orang khawatir akan terjadi penularan yang lebih masif. Di awal Covid-19 masuk Indonesia, di masyarakat beredar informasi bahwa empon-empon dapat menyembuhkan Covid-19. Fenomena yang muncul setelah berita tersebut, memicu persepsi masyarakat Desa Tehoru bahwa empon-empon bisa dijadikan obat tradisional untuk menyembuhkan Covid-19. Dari permasalahan tersebut maka, tim pengabdian mengadakan kegiatan sosialisasi mengenai upaya pencegahan penyebaran Covid-19 dan pemanfaatan tanaman herbal sebagai upaya pemeliharaan kesehatan tubuh sehingga upaya mencegah penularan lebih maksimal. Serta edukasi bagi masyarakat Desa Tehoru bahwa empon-empon itu belum terbukti secara klinis dapat menyembuhkan Covid-19, melainkan untuk menjaga kesehatan dari segi imunitas tubuh. Adapun hasil kegiatan yang dicapai dari kegiatan ini terdapat peningkatan pemahaman yang signifikan terutama pada masyarakat Desa Tehoru Kabupaten Maluku Tengah tentang upaya pencegahan penyebaran Covid-19 dan pemanfaatan tanaman herbal sebagai upaya pemeliharaan kesehatan tubuh.
\end{abstract}

Kata kunci: Covid-19, tanaman herbal, dan edukasi

\begin{abstract}
The spread of Covid-19 is so fast that all countries in the world are facing the same health problems. Indonesia is no exception, so far in Central Maluku Regency, the number of confirmed cases of COVID-19 has reached 20. This of course makes everyone worried that a more massive transmission will occur. At the beginning of Covid-19 entering Indonesia, information circulated in the community that empon-empon could cure Covid-19. The phenomenon that emerged after the news triggered the perception of the people of Tehoru Village that empon-empon could be used as a traditional medicine to cure Covid-19. From these problems, the service team held outreach activities regarding efforts to prevent the spread of Covid-19 and the use of herbal plants as an effort to maintain body health so that efforts to prevent transmission were maximized. As well as education for the people of Tehoru Village that the empons have not been clinically proven to cure Covid-19, but rather to maintain health in terms of body immunity. As for the results of the activities achieved from this activity, there was a significant increase in understanding, especially in the community of Tehoru Village, Central Maluku Regency about efforts to prevent the spread of Covid-19 and the use of herbal plants as an effort to maintain body health.
\end{abstract}

Keywords: Covid-19, herbal plants, and education

\section{PENDAHULUAN}

Covid-19 merupakan penyakit yang disebabkan oleh virus corona jenis baru. Awal mula dari penyebaran virus ini adalah Wuhan, China. Covid-19 adalah penyakit jenis yang belum pernah diidentifikasi sebelumnya pada manusia. Virus penyebab Covid-19 ini dinamakan SarsCoV-2. Virus coronona adalah zoonosis (ditularkan antara hewan dan manusia). Hasil penelitian menyebutkan SARS ditransmisikan dari kucing luwak (civet cats) ke manusia dan MERS dari unta ke manusia. Adapun hewan yang menjadi sumber penularan Covid-19 ini masih belum diketahui [1].

Corona virus adalah suatu kelompok virus yang dapat menyebabkan penyakit pada hewan atau manusia. Beberapa jenis coronavirus diketahui menyebabkan infeksi saluran nafas 
pada manusia mulai dari batuk pilek hingga yang lebih serius seperti Middle East Respiratory Syndrome (MERS) dan Severe Acute Respiratory Syndrome (SARS) [2].

Gejala-gejala Covid-19 yang paling umum adalah demam, batuk kering, dan rasa lelah. Gejala lainnya yang lebih jarang dan mungkin dialami beberapa pasien meliputi rasa nyeri dan sakit, hidung tersumbat, sakit kepala, konjungtivitis, sakit tenggorokan, diare, kehilangan indera rasa atau penciuman, ruam pada kulit, atau perubahan warna jari tangan atau kaki. Gejala-gejala yang dialami biasanya bersifat ringan dan muncul secara bertahap. Beberapa orang menjadi terinfeksi tetapi hanya memiliki gejala ringan [3].

Virus ini dapat ditularkan dari manusia ke manusia dan telah menyebar secara luas di China dan lebih dari 190 negara dan teritori lainnya. Pada 12 Maret 2020, WHO mengumumkan Covid-19 sebagai pandemik. Covid-19 adalah penyakit baru yang telah menjadi pandemi. Penyakit ini harus diwaspadai karena penularan yang relatif cepat, memiliki tingkat mortalitas yang tidak dapat diabaikan, dan belum adanya terapi definitif. Masih banyak knowledge gap dalam bidang ini sehingga diperlukan studi- studi lebih lanjut [4].

Penyebaran virus ini sangat cepat sehingga semua negara di dunia ini sedang menghadapi masalah kesehatan yang sama. Tak terkecuali di Indonesia [5]. Beberapa daerah terjadi transmisi lokal, seperti di Desa Tehoru Kabupaten Maluku Tengah. Hingga saat ini di Kabupaten Maluku Tengah pasien konfirmasi positif virus corona sudah mencapai 20-an. Hal itu tentu saja membuat semua orang khawatir akan terjadi penularan yang lebih masif. Untuk mencegah itu, pihak pemerintah telah melakukan berbagai upaya dimulai dari penutupan akses wisata, sosialisasi penerapan protokol kesehatan. Tak terkecuali di Desa Tehoru masih banyak warga yang kurang memahami virus corona itu sehingga dalam menerapkan protokol kesehatan masyarakat masih terkesan kurang maksimal. Di ruang publik masih banyak warga yang tidak menggunakan masker, kurang menjaga jarak, dan kesadaran untuk mencuci tangan setiap melakukan aktifitas dirasa masih kurang.

Di awal virus corona ini masuk Indonesia, di masyarakat banyak beredar informasi bahwa empon-empon dapat menyebuhkan Covid-19 [6]. Fenomena yang muncul setelah berita tersebut, memicu persepsi masyarakat Desa Tehoru bahwa empon-empon bisa dijadikan obat tradisional untuk menyembuhkan Covid-19. Dari permasalahan tersebut maka, tim pengabdian mengadakan kegiatan sosialisasi mengenai upaya pencegahan penyebaran Covid-19 dan pemanfaatan tanaman herbal sebagai upaya pemeliharaan kesehatan tubuh serta pembuatan tanaman obat keluarga sehingga upaya mencegah penularan lebih maksimal. Selain itu juga edukasi akan diberikan bagi masyarakat Desa Tehoru bahwa empon-empon itu belum terbukti secara klinis dapat menyembuhkan Covid-19, melainkan untuk menjaga kesehatan dari segi imunitas tubuh.

Obat tradisional juga dapat digunakan juga untuk anak- anak [7]. Obat tradisional bukan semata-mata hanya untuk wanita namun tersedia pula untuk laki-laki dan anak-anak. Obat tradisional memiliki beberapa keunggulan, seperti toksisitasnya rendah dan efek samping yang ditimbulkan ringan [8].

Dengan demikian diharapkan masyarakat Desa Tehoru dapat memahami secara komprehensif dan utuh bagaimana harus berperilaku di masa pandemi ini. Terkait dengan tanaman herbal, maka dengan kegiatan ini diharapkan masyarakat Desa Tehoru dapat paham akan manfaat tanaman obat keluarga yang merupakan bagian dari tanaman herbal dapat digunakan untuk mencegah Covid-19 dengan meningkatan imunitas tubuh seseorang. Edukasi dan sosialisasi kepada masyarakat di lakukan dengan metode tatap muka untuk berinteraksi secara langsung dengan memperhatikan protokol kesehatan.

\section{METODE}

Metode yang dilakukan, yaitu melalui sosialisasi kepada masyarakat Desa Tehoru Kabupaten Maluku Tengah terkait upaya pencegahan penyebaran Covid-19 dan pemanfaatan tanaman herbal sebagai upaya pemeliharaan kesehatan tubuh dengan beberapa cara berikut: 
a. Metode observasi lapangan, dilakukan untuk memetakan tempat dan lokasi sosialisasi dan pembuatan tanaman obat keluarga pada masyarakat khususnya di Desa Tehoru Kabupaten Maluku Tengah.

b. Sosialisasi kegiatan, dilakukan di Balai Desa.

c. Pembuatan Tanaman Obat Keluarga di beberapa lokasi di Desa Tehoru Kabupaten Seram Maluku Tengah

Berikut beberapa tahapan sosialisasi yang dilakukan oleh tim, sebagai berikut:

a. Tahap I (Observasi Lapangan)

Tim pengabdian melakukan kegiatan observasi lapangan yaitu di Desa Tehoru Kabupaten Maluku Tengah untuk lokasi sosialisasi dan pembuatan tanaman obat keluarga.

b. Tahap II (Kegiatan Perizinan)

Tim Pengabdian meminta izin kepada Kepala Desa Tehoru Kabupaten Maluku Tengah terkait kegiatan sosialiasi yang akan dilaksanakan. Sosialisasi ini bertujuan untuk meningkatkan pemahaman yang signifikan terutama pada masyarakat Desa Tehoru Kabupaten Maluku Tengah tentang upaya pencegahan penyebaran Covid-19 dan pemanfaatan tanaman herbal sebagai upaya pemeliharaan kesehatan tubuh.

c. Tahap III (Kegiatan Sosialisasi)

Sosialisasi upaya pencegahan penyebaran Covid-19 dilakukan pada hari Jum'at, 19 Maret 2021. Sosialisasi dilakukan dengan tetap memperhatikan protokol kesehatan, menggunakan masker, menerapkan kebiasaan cuci tangan dan penggunaan hand sanitizer, serta pembatasan jarak sosial. Sosialisasi yang dilaksanakan oleh tim dilakukan di Balai Desa Tehoru.

d. Tahap IV (Kegiatan Pembuatan Tanaman Obat Keluarga)

Kegiatan pembuatan tanaman obat keluarga dilakukan pada hari Sabtu, 20 Maret 2021. Lokasi pembuatan tanaman obat keluarga di Dusun Pasalolu dan Dusun Saju, Desa Tehoru Kabupaten Maluku Tengah.

\section{HASIL DAN PEMBAHASAN}

Kegiatan sosialisasi upaya pencegahan penyebaran Covid-19 dan pemanfaatan tanaman herbal sebagai upaya pemeliharaan kesehatan tubuh yang dilaksanakan di Desa Tehoru memiliki tujuan utama untuk meningkatkan pemahaman masyarakat terhadap Covid-19 serta memahami tentang pemanfaatan tanaman herbal untuk meningkatkan imunitas tubuh. Kegiatan berlangsung dengan lancer dengan sasaran utama adalah masyarakat Desa Tehoru Kabupaten Maluku Tengah. Kegiatan ini dimulai dari tahap persiapan dan pelaksanaan. Tahap persiapan merupakan tahapan yang cukup panjang guna memperoleh hasil yang baik dan berjalannya kegiatan ini dapat berjalan dengan lancar.

Kegiatan pengabdian masyarakat ini dimulai dari pengumpulan materi dan informasi tentang covid-19 secara komprehensif, artinya dilakukan pencarian mulai dari pengertian Covid-19 itu sendiri, penyebab, gejala, penanganan, sampai dengan upaya pencegahannya. Dari informasi ini kemudian dibuat inti sari yang mana akan dijadikan bahan materi untuk pembuatan pamflet tentang covid-19 hingga upaya pencegahannya. Media yang digunakan yaitu menggunakan Laptop dan LCD yang disajikan dalam bentuk Powerpoint sehingga dapat menarik perhatian dan memudahkan masyarakat untuk memahami isi secara keseluruhan materi dengan baik.

Hal lain juga demikian, pelaksana mengumpulkan materi tentang tanaman herbal, manfaat tanaman herbal, cara mengonsumsi tanaman herbal sebagai jamu guna meningkatkan kesehatan tubuh. Dari informasi yang didapatkan kemudian dibuatlah intisari materi yang akan 
dimuat dalam bentuk Powerpoint dengan menggunakan media Laptop dan LCD. Sehingga dapat menarik perhatian dan memudahkan masyarakat untuk memahami isi secara keseluruhan dengan baik. Sehingga tujuan pemahaman masyarakat umum tentang Covid-19 dan pemanfaatan tanaman herbal dapat tercapai.

Kegiatan berikutnya merupakan sosialisasi tentang Covid-19 dan pemanfaatan tanaman herbal sebagai jamu kepada masyarakat yang dilakukan secara langsung pada sasaran. Pada tahap persiapan dilakukan serangakaian persiapan guna menjadikan tujuan sosialisasi dan edukasi ini tercapai dengan maksimal. Dimulai dengan melakukan kunjungan kepada pihak pemangku desa, yaitu Kepala Desa Tehoru Kabupaten Maluku Tengah yang dilaksanakan di Kantor Balai Desa Tehoru. Dari hal tersebut didapatkanlah ijin untuk melaksanakan kegiatan di Desa Tehoru dengan diberikannya surat rekomendasi dari pihak desa.

Persiapan selanjutnya adalah dengan menyiapkan bahan-bahan sebagai sarana pendukung edukasi dan sosialisasi tersebut. Pembuatan materi tentang menggunakan masker dan handsanitizer yang benar. Hal itu bertujuan untuk memudahkan pelaksana dalam memberikan edukasi dengan gambar dan desain yang menarik sehingga mudah untuk dipahami oleh sasaran. Kedua, menyiapkan masker dan handsanitizer.

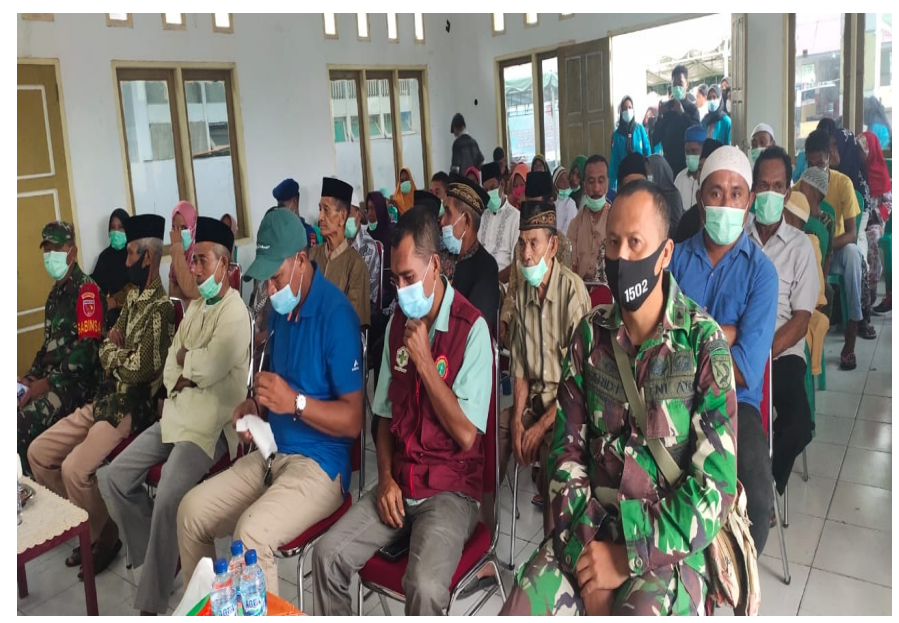

(a)

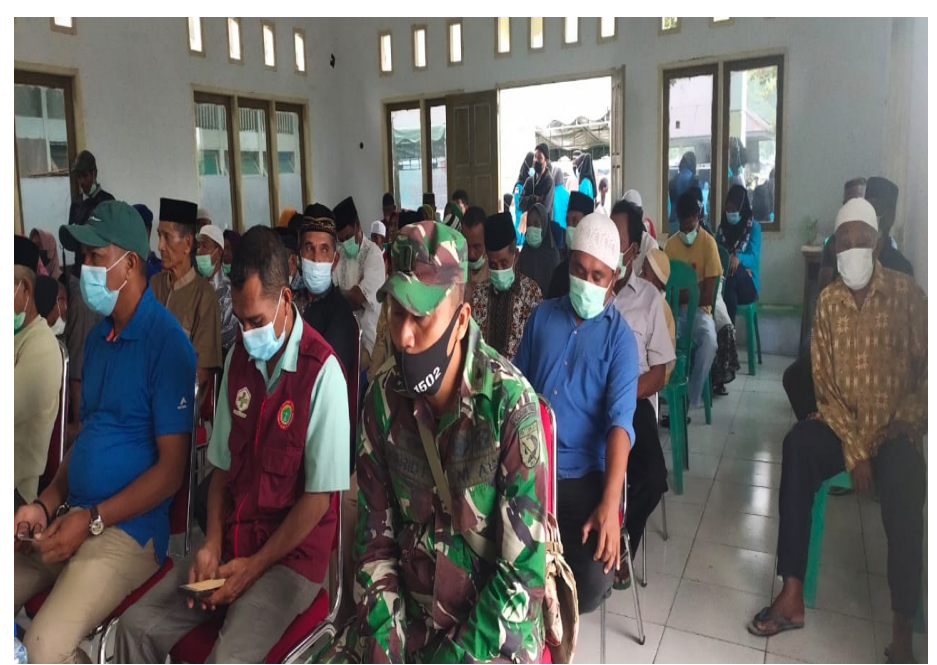

(b)

Gambar 1. (a) dan (b) Sosialisasi upaya pencegahan penyebaran Covid-19

Pada pelaksanaanya, masyarakat Desa Tehoru rata-rata masih rendah pengetahuannya terhadap Covid-19. Sehingga hal ini berdampak pada bagaimana mereka berperilaku sehari-hari. Contohnya adalah kesadaran penggunaan masker masih rendah, dan tingkat intesitas mencuci tangan yang cukup rendah. Kemudian sosialisasi dilaksanan dengan mengedukasi mereka 
tentang bagaimana seharsnya bersikap di masa pandemi ini. Dari hasil berbincang-bincang dengan beberapa masyarakat didapatkan bahwa sasaran menunjukan tingkat pengetahuan yang lebih baik tentang covid-19. Ketika mereka ditanya apa itu Covid-19 mereka sudah bisa membedakan antara penyakit dan hal yang menyebabkannya. Mereka lebih paham mengenai bagaimana gejala klinis dari Covid-19. Mereka juga lebih memahami bagaimana cara utama untuk mencegah penularan Covid-19. Antusiasme ini merupakan semangat bersama untuk belajar bersama sehingga dapat meningkatkan kepatuhan mereka dalam menerapkan protokol kesehatan yang telah dibuat pemerintah utamanya ketika mereka berada di ruang publik. Mereka juga lebih memahami pentingnya menjaga diri sendiri dan orang lain, kepedulian inilah menjadi salah satu parameter dalam suksesnya kegiatan ini.

Para masyarakat, ketika ditanya apa manfaat dan bagaimana cara mengonsumsi jamu dengan benar, sebagian mereka cukup tahu tentang beberapa manfaat jamu, namun hal itu masih dangkal, dan beberapa dari mereka kurang memahami manfaat jamu tersebut terlebih bagaimana mengonsumsinya dengan benar. Sosialisasi dilaksanakan pada masyarakat Desa Tehoru ini dengan metode edukasi dengan menggunakan ilustrasi gambar sehingga memudahkan komunikasi antarpersonal. Hasilnya rata-rata mereka paham bahan apa saja yang dapat dimanfaatkan sebagai jamu. Mereka juga paham apa tanaman-tanaman herbal tersebut bagi kesehatan tubuh. Mereka juga lebih paham bagaimana cara mengonsumsi jamu dengan benar dengan menggunakan takaran yang tepat sesuai dengan penelitian yang ada. Mereka juga menjadi paham siapa-siapa saja yang boleh dan tidak boleh mengonsumsi jamu pada kondisikondisi tertentu, misalnya wanita hamil, penderita penyakit kronis, terlebih pada hati, alergi pada bahan tertentu.

Selain itu, tim pengabdian melakukan kegiatan pembuatan tanaman obat keluarga dilakukan pada hari Sabtu, 20 Maret 2021. Lokasi pembuatan tanaman obat keluarga di Dusun Pasalolu dan Dusun Saju, Desa Tehoru Kabupaten Maluku Tengah.

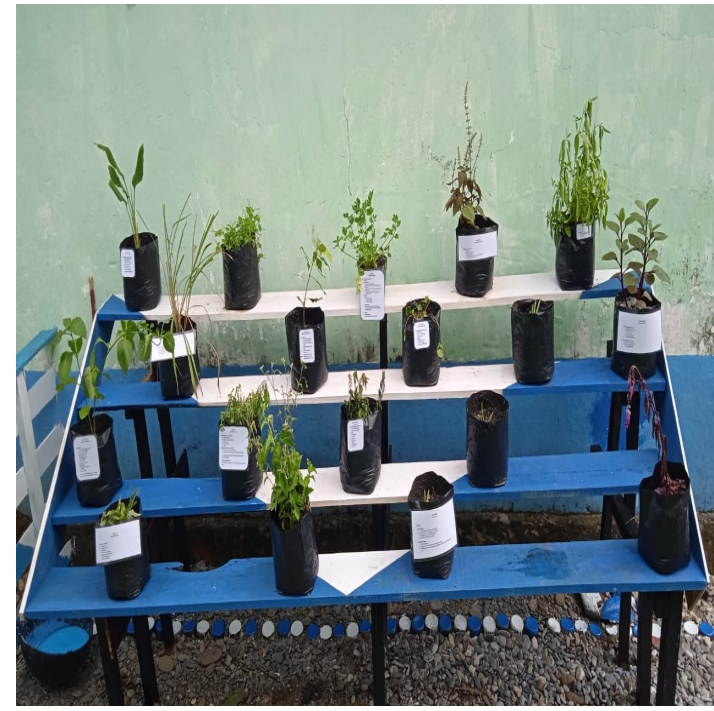

(a)

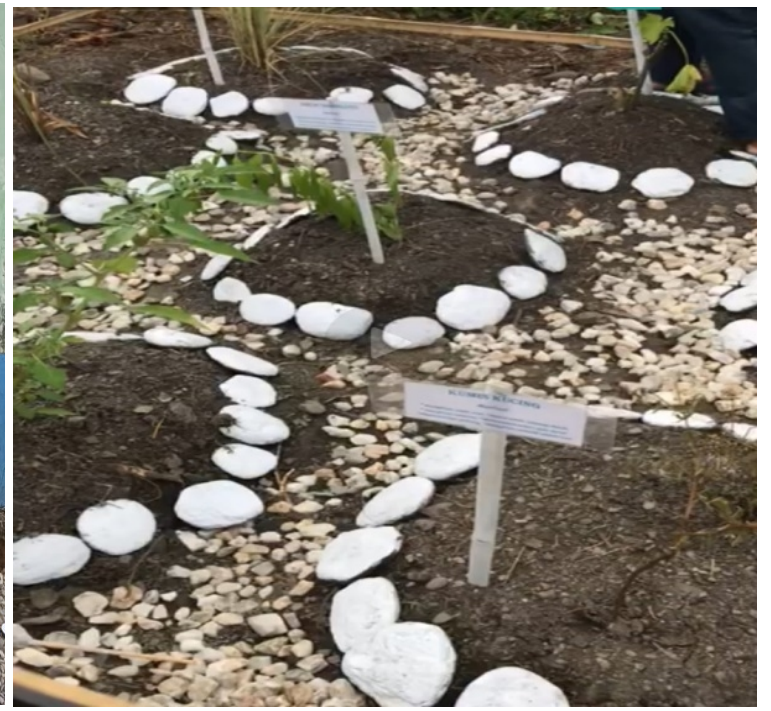

(b)

Gambar 2. (a) Pembuatan Tanaman Obat Keluarga di Dusun Pasalolu dan (b) di Dusun Saju

Kegiatan sosialisasi edukasi kepada mayarakat Desa Tehoru dapat dikatakan berjalan dengan lancar dan baik. Kegiatan ini sudah menjawab tujuan awal yaitu memberikan pemahaman yang komprehensi bagi masyarakat Desa Tehoru dengan memberikan edukasi dan sosialisasi tentang Covid-19 dan pemanfaatan tanaman herbal sebagai jamu untuk meningkatkan kesehatan. Dimuali dari pemahaman masing-masing pribadi inilah kemudian diharapkan mereka akan mengimplementasikan protokol kesehatan dalam kegiatan sehari berjualan jamu secara keliling dan dapat turut memberikan informasi manfaat jamu dan cara mengonsumsi jamu dengan benar. Di masa yang akan datang akan lebih baik untuk mengadakan 
pelatihan pembuatan jamu yang tepat guna meningkatkan kualitas jamu dengan narasumber seorang ahli dalam bidang farmakognosi dan fitokimia.

\section{KESIMPULAN}

Bentuk pengabdian masyarakat dengan kegiatan sosialisasi dan edukasi tentang upaya pencegahan penyebaran Covid-19 dan pemanfaatan tanaman herbal sebagai jamu untuk meningkatkan kesehatan tubuh di Desa Tehoru Kabupaten Maluku Tengah dengan tujuan untuk memberikan pemahaman terkait hal dia atas secara komprehensif dan tepat pada masyarakat dengan baik dengan tercapainya pemahaman tentang covid-19 dan pemanfaatan tanaman herbal. Dari pemahaman tersebut munculah kesadaran diri akan menerapkan protokol kesehatan dalam kehidupan sehari-hari untuk mencegah penularan covid-19 dan timbulnya kesadaran bahwa jamu merupakan bagian supportif untuk meningkatkan kesehatan dengan meningkatkan imunitas tubuh.

\section{DAFTAR PUSTAKA}

[1] Kemenkes RI, "Pedoman Pencegahan dan Pengendalian Coronavirus Disease (Covid-19)," Math Didact. J. Pendidik. Mat., pp. 1-214, 2020, doi: 10.33654/math.v4i0.299.

[2] D. P. Wijaya, B. Untari, and V. Agustiarini, "Sosialisasi Upaya Peningkatan Imunitas Tubuh dan Pemanfaatan Tanaman Obat Keluarga (TOGA) sebagai Minuman Kesehatan pada Masa Pandemi Covid-19 di Desa Pulau Semambu Inderlaya," J. Pengabdi. Sriwij., no. september, pp. 1192-1197, 2020.

[3] D. Harniawati and T. Y. Widya, "TOCAP (Toga Education Program) Melalui Peningkatan Pengajaran Edukatif tentang Penerapan Hidup Sehat pada Sekolah Dasar di Kediri," Pros. Semin. Nas. Biol., vol. XI, pp. 1084-1087, 2014.

[4] M. N. Fathoni, "Edukasi Tentang Covid-19 Serta Pemanfaatan Tanamaan Herbal Pada Pedagang Jamu Keliling Di Desa Tanjungsari," J. Layanan Masy. (Journal Public Serv., vol. 4, no. 2, p. 479, 2020, doi: 10.20473/jlm.v4i2.2020.479-485.

[5] N. M. S. Muryani, "PemanfaatanTanaman Obat Keluarga ( TOGA ) di Masa Pandemi COVID19," Jayapangus Press, 2020.

[6] D. Pucang and K. Secang, "Pelatihan Penanaman TOGA sebagai Upaya Pencegahan Penyebaran Covid- 19 di Desa Pucang," Univ. Negeri Semarang, no. 1, 2020.

[7] A. L. Sunarwidhi, D. G. Wirasisya, and N. I. Hanifa, "Sosialisasi Pemanfaatan TOGA Dan Pembuatan Sabun Batang Alami (Sabun Aloe vera) Kepada Murid Yayasan Generasi Muslim Cendekia di Lombok Tengah, Indonesia," J. Pengabdi. Magister Pendidik. IPA, vol. 3, no. 2, pp. 149-155, 2020, doi: 10.29303/jpmpi.v3i2.513.

[8] M. Atmojo and A. Darumurti, "Pemberdayaan Masyarakat Melalui Tanaman Obat Keluarga (TOGA)," J. Abdimas BSI J. Pengabdi. Kpd. Masy., vol. 4, no. 1, pp. 100-109, 2021, doi: 10.31294/jabdimas.v4i1.8660. 